\title{
'The families were ... too poor to send them parcels': The provision of comforts to Aboriginal soldiers in the AIF in the Second World War
}

Kristyn Harman

In mid-1941, Private Clarrie Combo from New South Wales sent a letter from Syria, where he was stationed, to Mrs Brown of Loxton in South Australia. Combo, an Aboriginal soldier serving abroad with the Second Australian Imperial Force (AIF), wrote 'it is very nice of you to write to someone you do not know. Thank you for offering to knit a pair of socks for me. I wear size seven in boots'. ${ }^{1}$ These unlikely correspondents formed an affective relationship during the Second World War under the auspices of a scheme designed specifically to cater for the needs of Australian Aboriginal men serving abroad. Following the outbreak of the war, in August 1940 the Victorian-based Aborigines Uplift Society launched a national comfort auxiliary. This was Australia's first fund with the express intent of providing comforts for Aboriginal soldiers, and its founding, modus operandi and outcomes are the subject of this article.

Combo was one of at least 3,000 Aboriginal and 850 Torres Strait Islander people known to have served Australia during the Second World War. ${ }^{2}$ The advent of war, as Kay Saunders has revealed, raised numerous complex questions in relation to the nation's Indigenous peoples, particularly in relation to their skills, capacity to serve, and loyalties. This led to some inequalities in relation to opportunities to serve. From a legal perspective, only those Aboriginal men who were exempt

\footnotetext{
1 Murray Pioneer and Australian River Record, 25 September 1941; Richmond River Herald and Northern Districts Advertiser, 7 February 1941.

2 Hall 1997: 189; Huggonson 1994: 11.
} 
from the provisions of various state-based Aboriginal Protection legislations were obliged to undertake compulsory military training in accordance with Section 61(1)(h) of the Defence Act 1909 (Cth). This meant that 'only those not identifying culturally as Aborigines and were thus recognised by bureaucratic procedures were obliged to join the Australian Imperial Force or the Australian Military Force'. This restricted the number of Aboriginal men who were afforded opportunities to serve Australia as soldiers. Ultimately, though, numerous Aboriginal men and women served their country on the homefront in a range of labouring capacities rather than in overseas theatres of combat. ${ }^{3}$ For example, noted anthropologist Donald Thomson later recounted how he was instrumental in establishing the Northern Territory Special Reconnaissance Unit, comprising warriors from Arnhem Land who played 'both a coastwatching role, like that of the Solomon Islanders and a harassing role like that of the Independent Companies, [in case] the Japanese should invade'. ${ }^{4}$

As the Second World War broke out, Australian states and territories were actively pursuing policies of assimilation. In Combo's home state of New South Wales, for example, the Aborigines Welfare Board's stated aim was 'to prepare the aboriginal people for citizenship', towards which end it claimed that 'every endeavour is being made to educate the dark-skinned people so that they will be able eventually to adjust themselves to the white man's way of life' ${ }^{5}$ Some Aboriginal people were confined within the parameters of government reserves, training homes, or missions and were consequently materially poor. Others were working in the lower echelons of wider society, filling roles as domestic servants or agricultural labourers, often receiving low wages. Under these circumstances, it is unsurprising to find that the Aborigines Uplift Society's comforts auxiliary had its inception in the notion that the Aboriginal families, friends and communities of those Aboriginal men serving abroad were too impoverished to be able to provide them with the same level of comforts as other Australian soldiers. It is necessary to exercise some caution in relation to the Aborigines Uplift Society's claims, however, because as Fiona Paisley has pointed out in a comparative context, such depictions cannot simply 'be taken as fact'. Paisley, writing in relation to white middle-class women's perceptions of Aboriginal poverty, found that 'the account they gave of Aboriginal status and conditions reflected their own version of history' ${ }^{6}$ In a similar way, the Aborigines Uplift Society's opinions as to Aboriginal people's living conditions would have been inflected by the standpoints of their predominantly white middle-class committees and membership. No doubt, though, the Society's Victorian members' views would have been at least in part informed by the

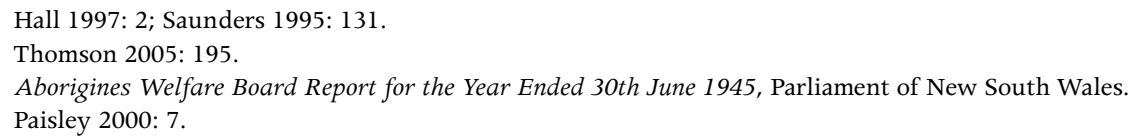


knowledge that parcels of 'clothing, kitchen utensils, furniture, in fact anything useful' that were prepared by the Society's Ladies Committee were 'always welcomed ... for passing onto the coloured people of Lake Condah district' ${ }^{7}$ The charitable scheme founded to assist Aboriginal men serving abroad could be seen as an extension of similar activities already being engaged in by branches of the Aborigines Uplift Society on home soil.

The Aborigines Uplift Society's new national comforts auxiliary was organised to procure volunteers who were willing to write to Aboriginal soldiers and to send the men parcels of comforts such as knitted garments, newspapers, chocolate, and toiletries. The terminology used, in that volunteers were asked to 'adopt' an Aboriginal soldier, resonates with the paternalistic ethos of the Aborigines Uplift Society and with the wider imperatives driving assimilatory policies from the early colonial period well into the twentieth century. In addition to forging links between individuals such as Combo and Brown, the Aborigines Uplift Society called for support to help establish and build a general comfort fund from which Aboriginal soldiers could be provisioned as required. ${ }^{8}$ Few records pertaining to the Aborigines Uplift Society's activities in relation to its national comforts auxiliary seem to have survived. However, its newsletter, Uplift, which has survived, provides a helpful chronological account of the inception and development of the comforts auxiliary, and local newspaper accounts from around Australia help to provide further context. Perhaps because of a paucity of archival source material, the Aborigines Uplift Society has consistently received only several lines of mention in relevant scholarly literature. ${ }^{9}$ It has proven difficult to locate much material illustrating Aboriginal responses to, and involvement with the national comforts auxiliary and comfort funds more generally. However, this is redressed at least partially through attention being given to the complexities of Aboriginal people's positioning within, and relationships with such organisations through considering the case study of Cummeragunja.

Despite the Aborigines Uplift Society's perception that Aboriginal people were not well-placed to provide comforts for soldiers, evidence has survived that demonstrates how, albeit from within the confines of a number of reserves and missions, many Aboriginal people - particularly women and children - were in fact heavily involved in raising funds and producing items of comfort for

\footnotetext{
7 'Hamilton Aborigines Uplift Society Monthly Meeting', c. 1942, Series 28, BARIO1976, State Library of Victoria.

8 'Comforts auxiliary', Uplift: The Official Organ of the Aborigines Uplift Society, vol. 2, no. 2, August 1940: 14, NLA.

9 For example, Attwood and Markus included the Aborigines Uplift Society twice in their book (2004: 113, 121); John Ramsland and Christopher Mooney recorded the Aborigines Uplift Society in Victoria as being 'of particular importance' in the 1930s in a footnote in their 2006 book; Robert Hall mentioned the Aborigines Uplift Society only fleetingly in his 1995 monograph.
} 
Aboriginal soldiers. They also supported the nation's war effort more generally under the auspices of a range of patriotic funds. As Michael McKernan has explained, 'the comforts business ... [was accepted as] part of women's traditional role in war'. ${ }^{10}$ The work associated with providing comforts seems to have retained its uncontroversial nature when extended to Aboriginal volunteers. While Noah Riseman has shown how a number of Aboriginal women managed to escape the constraints of assimilation-era Australia through employment in the armed services women's auxiliaries, conversely the New South Wales Aborigines Welfare Board utilised the participation of Aboriginal women and children in the production of comforts to demonstrate its apparent success in preparing Aboriginal people for their eventual assimilation into wider Australian society. ${ }^{11}$ This practice bears some similarities to the ways in which Australian media outlets promoted the First World War Aboriginal soldier Douglas Grant, and Reginald Saunders who served in the Second World War, as well as other Aboriginal servicemen, as models of assimilation in twentiethcentury Australia. ${ }^{12}$

\section{Founding the Aboriginal Uplift Society's national comforts auxiliary}

The provision of comforts to Australian soldiers deployed overseas during the Second World War ensured the men were better provided for with regard to material items such as canteen orders, kit, newspapers and correspondence than would otherwise have been the case. Across the homefront, a veritable army of men, women and children voluntarily raised funds, baked goods, knitted and sewed garments, and wrote letters to soldiers to contribute to the various comfort funds as part of the war effort. As Joan Beaumont recently demonstrated, the emergence of patriotic funds such as the Australian Red Cross Society, Australian Comforts Fund and the Salvation Army during the First World War followed the devastating defeat on Gallipoli, which triggered a realisation 'that a more systematic mobilisation of the home front was needed'. More volunteers were required, not only to replace the fallen but to tend to the needs of bereaved families, repatriated men and those who remained at the front. ${ }^{13}$

Observing how 'war work was much more than a tiresome tally of socks, balaclavas, and pyjamas', Bruce Scates has shown how female volunteers in particular invested 'enormous emotional labour' not only in the production

10 McKernan 2014: 54.

11 Riseman 2015: 757-775.

12 Riseman 2014: 155-178.

13 Beaumont 2014: 94. 
of these necessary commodities but also in other voluntary capacities such as 'mediators of grief and bereavement' ${ }^{14}$ Beaumont states that with limited social services available across Australia, the federal and state governments 'relied to a degree that seems remarkable ... on a volunteer mobilisation in the form of the patriotic funds movement' ${ }^{15}$ By 1938, as Melanie Oppenheimer has explained, the Australian Red Cross Society, the Australian Comforts Fund and the Salvation Army had become Australia's 'designated war charities to work with the armed forces in the event of war', with the YMCA being accorded the same status in 1942. ${ }^{16}$ Yet none of these comfort funds had a specific mandate to provide for Aboriginal soldiers. In late 1939, the Victorian-based Aborigines Uplift Society stepped in to breach this gap.

In December 1939, the founder and secretary of the Melbourne-based Aborigines Uplift Society and editor of its regular journal Uplift, trade unionist Arthur Burdeu, told his readers that it would 'not be news to some to know that many hundreds of aborigines fought in the Great War'. Burdeu went on to explain, however, that 'it may not be known that many gave their lives, and their blood is mingled in the fields of Flanders and Palestine with that of their white brothers'. His key point was that despite many Aboriginal people having served their country during the First World War, those repatriated to Australian soil following its conclusion had been returned to 'a sub-human status' through, as the Society described in further discourse on this topic in 1940, having had to 'hand in their manhood with their uniforms'. Written in the context of the recent outbreak of the Second World War, Burdeu advocated strongly that any Aboriginal people who enlisted in the current conflict 'must come [home] to a status the equal of their white comrades'. At the time of the journal's publication, many Aboriginal men were already known to be keen to enlist in the Second Australian Imperial Force. ${ }^{17}$ As Anne $\mathrm{O}^{\prime}$ Brien has explained, Burdeu worked closely with the prominent Aboriginal activist William Cooper. Her observation, though, that 'white organisations worked for [the 'betterment' or 'uplift' of], rather than with, Aboriginal people' is generally borne out in this article. ${ }^{18}$

In August 1940, the Society publicised the fact that many Aboriginal people had enlisted into the armed forces across New South Wales and Victoria, with some already in England and others in Palestine. Many more remained in camp in Australia. However, rumours were circulating that moves were afoot to prevent

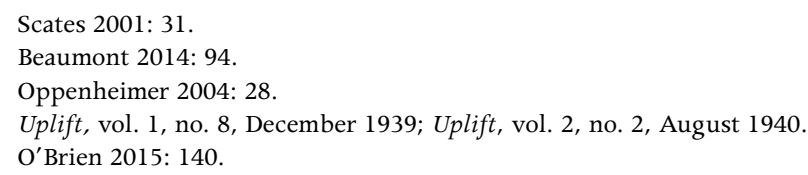


any more Aboriginal people from enlisting. ${ }^{19}$ Despite such rumours, which were indicative of continuing tensions at official levels surrounding Aboriginal involvement in the armed forces, the Aborigines Uplift Society continued to voice concern over the treatment meted out to those Aboriginal people who had served during the First World War following their return to Australia. Remembering their poor treatment, Burdeu reported that the Society's council had taken a decision to advocate for the rights of those who enlisted to serve their country during the Second World War. He wrote to the Prime Minister to argue that those Aboriginal people enrolled in the Australian Imperial Force ought to be granted Australian citizenship. Burdeu conjectured that 'surely this will not be declined'.$^{20}$ While advocacy was one of the strategies utilised by the Aborigines Uplift Society in its endeavours to better the living conditions and opportunities for Aboriginal people across Australia, it also played a key role in providing practical help to those serving abroad.

In the same edition of Uplift in which Burdeu publicised the Society's proposed advocacy role, he announced its establishment of a comfort fund for Aboriginal soldiers. Its aim was to organise the sort of support 'that will put our native soldiers on the level with white soldiers with mothers, wives and sweethearts, not to mention friends, who can send them comforts'. Such comforts might include, for example, letters as well as toiletries, foodstuff, and knitted garments such as socks, hats, and scarves, and such like. 'It need not be stressed', the Aborigines Uplift Society reminded its readership, 'that native women have not the resources to do as their white sisters'. The Society envisaged a national (rather than a state-based) scheme whereby some volunteers would be involved in corresponding with the soldiers, while others would provide comforts either to nominated soldiers or generally to a comfort fund from which such comforts might then be distributed to Aboriginal soldiers as and when they were needed. Some women had already offered their services, but one impediment standing in the way of the provision of much-needed support to Aboriginal soldiers was information as to their military addresses. 'Our Comforts Work is being retarded for the want of information', Burdeu told his readers, urging them either to provide any addresses they knew of, or to endeavour to obtain such details and to pass them on to the Aborigines Uplift Society. ${ }^{21}$ Because the military did not record the 'race' of those who enlisted, it was only possible to identify Aboriginal soldiers through garnering community knowledge.

By November 1940, 'several women' had expressed an interest in working as part of the comforts auxiliary. However, some difficulties were still being experienced in obtaining the full military addresses of all of those who had enlisted. Burdeu

19 Uplift, vol. 2, no. 2, August 1940.

20 Uplift, vol. 2, no. 2, August 1940.

21 Uplift, vol. 2, no. 2, August 1940. 
asked readers to provide the Society with at least the names of those who had enlisted and the location at which they had signed up. From these scant details, it was often possible to then obtain their military addresses. This was made easier if informants were able indicate to which unit each man belonged. Given that the Society saw fit to print in capital letters its exhortation to provide contact details for Aboriginal soldiers 'no matter what state they had enlisted in', it can be surmised that at least some people may have incorrectly assumed the comforts auxiliary to be a state-based rather than a national scheme. It was, however, the Society's intention to send comforts to every Aboriginal soldier from across the nation who was serving abroad with the AIF. ${ }^{22}$ In February 1941, it was also actively seeking information on 'half castes' who had joined the navy so that these men, too, could benefit from the receipt of comforts. While 'a large number of helpers' had already committed themselves to carry out this work, still more volunteers were being sought to assist in the work of the comforts auxiliary. ${ }^{23}$

\section{'Adopting' Aboriginal soldiers}

From the outset, the Aborigines Uplift Society intended that those involved in its comfort auxiliary as 'workers will be both native and white women'. ${ }^{24}$ Articles predominantly aimed at recruiting white women ran in newspapers across Australia, explaining how the Aborigines Uplift Society was caring for Aboriginal soldiers in the AIF under its comforts auxiliary. 'Each worker writes to an allotted man', explained the Advertiser to its South Australian readership, 'and sends him comforts such as canteen orders, socks, and newspapers'. More volunteers were being actively sought, with those women who were interested in 'adopting' an Aboriginal soldier being urged to write to the Society's secretary, A. P. A. Burdeu, at his Melbourne address to obtain 'particulars' ${ }^{25}$ In Queensland, Courier Mail columnist Winifred Moore informed her readers that she had received a letter from Burdeu. In it he explained how the 'Friendly Service to Aborigines' that he organised was interested in receiving names and address details 'of any native Australians in the AIF - whether full blood Aborigines, half caste, or kanakas - so that they may share in the benefits of the organisation he represents'. Burdeu had told Moore that while there was 'quite an army of women in each state' involved in providing comforts for Aboriginal soldiers, more volunteers were required. Some soldiers were yet to be allocated to a volunteer, and as more names and addresses of Aboriginal

22 Uplift, vol. 2, no. 3, November 1940.

23 Uplift, vol. 2, no. 4, February 1941.

24 Uplift, vol. 2, no. 2, August 1940.

25 Advertiser, 24 June 1941. 
servicemen became available, yet more volunteers to correspond with and provide material comforts to them would be needed. Once again, any women interested in volunteering for this 'uplift and patriotic service' were invited to write directly to Burdeu in Melbourne. ${ }^{26} \mathrm{~A}$ similar call for volunteers was issued through the columns of the West Australian newspaper, with it being noted that as a number of Western Australian Aboriginal men were serving overseas with the AIF, some local women might want to volunteer to join the work of the Aborigines Uplift Society's comforts auxiliary. The information provided to prospective volunteers in other states was repeated in Western Australia, with the usual remarks about correspondence with the men supplemented with an observation by Burdeu that women who wrote to Aboriginal soldiers were receiving 'interesting letters' in return. ${ }^{27}$ In Tasmania, several Girl Guide companies became involved in providing comforts to Aboriginal soldiers after having heard from Burdeu about the Aborigines Uplift Society's initiative. ${ }^{28}$

Despite Burdeu's assurances that correspondents could anticipate receiving interesting letters from Aboriginal soldiers, at least one woman seemed surprised by the correspondence she received. Referred to in a newspaper report simply as 'a Camperdown well-wisher', the woman in question had responded to Burdeu's plea for volunteers and had been allocated an Aboriginal soldier to whom she had written 'in as simple a language as possible, of the things she thought he would best understand'. She reportedly had hoped 'at best' to receive 'a crudely worded missive, rounded off, no doubt, by the padre, or some other similarly friendly member of the unit' in reply. Instead, the correspondent was very surprised to receive a letter composed using 'English well above the average' in which the Aboriginal soldier to whom she had written provided a first-hand, albeit heavily censored, account of his activities as part of an AIF field ambulance squad. The Camperdown Chronicle reported receipt of the Aboriginal soldier's letter, commending it not only on the basis of its 'literary merit', but also because the correspondent had, in his own words, reported how 'we have been through some tough times together, and it has brought all the boys closer to each other'. This sentence, according to the newspaper in which it was reproduced, painted 'a picture for us of the freemasonry which has always characterised the AIF'. The soldier, the newspaper commentary continued, 'has quite unconsciously administered a well-deserved rebuke to us in this class-prejudiced world - a world which, in civil life, stubbornly refuses to recognise this man's existence' ${ }^{29}$ While some Aboriginal soldiers experienced a measure of equality while serving alongside other Australian men, on their return to Australian soil any equality largely evaporated. Interestingly, the

26 Courier Mail, 27 November 1941.

27 West Australian, 23 June 1941.

28 Harman 2015.

29 Camperdown Chronicle, 8 July 1941. 
newspaper described such socioeconomic discrimination as being predicated on the grounds of class rather than race. However, it was racial stereotyping that saw many Aboriginal people incorporated into the lower classes of Australian society, if they were incorporated at all.

To emphasise the apparently unanticipated and surprising level of literacy displayed by the Aboriginal correspondent, the Camperdown Chronicle proceeded to provide a series of direct quotations from his letter. This commenced with an expression of gratitude for the letter and canteen order that he had received, followed by a description of the type of work the field ambulance was engaged in, the camaraderie he was experiencing within his unit, and his thoughts of home. The soldier, who was a medical orderly, explained how the Comforts Fund and Red Cross had 'things ready for us' when he and his comrades landed in Egypt. Having recently returned from four days' leave in Jerusalem at the time of writing, he had obtained a small souvenir from Palestine, which had been enclosed with his letter as a gift to the 'well-wisher' correspondent. He assured her that he found his work 'really worthwhile'. 'What is a better way of serving one's country', he wrote, 'than by trying to keep her men alive'. He went on to describe himself as a married man from Victoria, who had 'the most wonderful wife in the world', with whom he had had two sons and two daughters. Two of these children were attending school. Having been amongst the first troops to depart Australia, on 14 April 1940, the correspondent was rather homesick and was missing his family. ${ }^{30}$

Affective relationships formed between some of the middle-class white women and girls and the Aboriginal soldiers whom they 'adopted', lasting at least for the duration of the period over which the providers and recipients of comforts corresponded. Such bonds, for the women involved, are consistent with Scates' concept of emotional labour and could be discerned in the correspondence between Combo and Brown mentioned at the beginning of this article. In a similar vein, in Tasmania, several companies of Girl Guides became involved in writing and sending comforts to Tasmanian Aboriginal soldiers serving abroad with the AIF, following the lead of some Launceston Girl Guides who 'adopted' two such soldiers in $1941 .{ }^{31}$ As discussed at the Girl Guides' Northern District Association meeting in July of that year, it was understood that the families of the aboriginals were too poor to send them parcels such as are received by other men of the AIF'. The Girl Guides therefore determined to send letters and

\footnotetext{
30 Camperdown Chronicle, 8 July 1941.

31 Despite the international sensation following the death in 1876 of Truganini, who was seen as symbolising 'the last of the race', people of Tasmanian Aboriginal descent continued to live on the main island of Tasmania and to populate offshore islands, particularly in Bass Strait. Despite claims to the contrary, successive Tasmanian governments recognised the existence of people of Aboriginal descent in Tasmania, although, consistent with racial thinking of the time, in the early decades of the twentieth century such people were referred to (and referred to themselves) as 'half castes'. See Harman 2013: 747.
} 
parcels of comforts to these men, with each girl doing various chores to raise funds or otherwise contributing small amounts of her pocket money, foregoing, for example, the purchase of sweets. ${ }^{32}$ By March 1942, no fewer than 16 tins of comforts had been sent to the two soldiers 'adopted' by the Launceston Girl Guides. At the same time, in March 1942, the girls got what was described in their local newspaper as 'a grand surprise' when they received an appreciative letter from one of the recipients, the contents of which remained unpublished and are therefore unavailable for further analysis. ${ }^{33}$

\section{Aboriginal women's and children's roles in producing comforts for soldiers}

Aboriginal women and children, too, joined in the work across the homefront of producing comforts for Australian soldiers serving abroad, some items of which would have been distributed specifically to Aboriginal soldiers and others to Australian soldiers more generally. Their involvement extended beyond the Aborigines Uplift Society's national comfort auxiliary, with practical assistance being provided through various local branches of the Australian Comforts Fund, as well as under the auspices of other organisations such as the Red Cross and the Country Women's Association (CWA).

Oodgeroo Noonuccal, who joined the Australian Women's Army Service in the Second World War (being one of several members of her family to enlist), noted how 'all of a sudden the colour line disappeared' once there was a war to be fought. Using a local example to highlight her point, she explained how there had been 'a tremendous colour bar' on Stradbroke Island off the coast of Queensland prior to the Second World War. However, when the war began the women who joined the local branch of the Australian Comforts Fund 'broke down this silly barrier of racial discrimination'. As Noonuccal explained, 'the white women ... went to the black women here on the island, and said, "Look, you make socks better than us, you are better at all these things", and recruited them into the newly established organisation. Significantly, both the Aboriginal and white women involved in producing comforts had sons serving their country in overseas theatres of war. ${ }^{34}$ As the following examples illustrate, the women at Stradbroke Island were far from the only Aboriginal women to be working together with white women in providing comforts for Australian soldiers.

32 Examiner, 9 July 1941.

33 Examiner, 18 March 1942.

34 Hall 1995: 118-119. 
Aboriginal children at the Purga Aboriginal Mission on the outskirts of Ipswich in Queensland were involved in knitting and sewing items to be distributed to soldiers through the Peak Crossing branch of the Australian Comforts Fund. The Peak Crossing branch, which also utilised the labour of Peak Crossing school children in manufacturing the required items, had in the year to March 1941 purchased 480 skeins of wool and 193 yards of material with funds raised through providing 'entertainments' that had been well attended by patriotic locals. These raw materials were then converted by children at the local Aboriginal mission and state school into useful items of clothing for soldiers serving abroad, such as knitted socks, balaclavas, and mittens, and sewn items such as pants, storage items (including calico bags and toilet tidies) and hussifs (or 'housewives', that is, sewing kits). These items were supplemented by other practical items of comfort such as soap, toothbrushes and toothpaste, and items that might be considered luxuries such as gramophone records and tins of tobacco.

Mr O. Brown, a local councillor who was present at the branch's first annual meeting held at the town hall in March 1941, observed that if only they [the branch members] knew what the comforts meant to the soldiers out in the desert, they would know that their work was not in vain'. Brown himself had served during the First World War, and speaking from personal experience he told the meeting 'how happy it made the soldiers to receive parcels of comfort'. Various other local dignitaries encouraged the female committee members to keep up their good work, with one being particularly pleased to learn that at least some of the comforts provided through the branch had been sent to Port Moresby. ${ }^{35}$

Farther south, at the Cabbage Tree Island Aboriginal Station at the Richmond River near Evans Head in New South Wales, which was home to 110 Aboriginal people, an Aborigines' Ladies Guild was formed during 1940 under the leadership of the Matron, Mrs J. P. Howard. The Guild organised a number of events throughout the year. These included a 'patriotic dance' held early on at which $£ 13$ was raised towards the war fund, and, towards the end of the year, a sports day with close to 200 Aboriginal people in attendance. As part of the latter event, a large Christmas tree decorated with 'bells, balloons and streamers, and laden with presents and a bag of lollies for each child on the island' had been erected, with Santa Claus also paying a visit. Presents were distributed to the Aboriginal parents and elders, 'comprising useful articles made by boys and girls at the sewing class'. In addition to crafting Christmas gifts for the adults on the island, the children had been involved in collecting 'large quantities of 
waste material' for recycling, while Guild members had knitted a range of items including socks, mittens and scarves for Aboriginal soldiers, both those at home and those serving abroad. ${ }^{36}$

The children's efforts continued throughout the war years, with their being involved in knitting and sewing garments for the war effort under the auspices of the Lismore branch of the CWA. The CWA provided the necessary fabric to the Cabbage Tree Island Settlement, from which the children stitched the required garments. In 1942, under the guidance of Matron Howard, the children crafted 'a unique cot quilt' with scraps of material left over from making pyjamas. Each of the 48 children involved in this handiwork neatly embroidered their name within one of the squares that made up the 'nicely worked' piece. The quilt was displayed in the window of the CWA's knitting depot in Magellan Street in Lismore. ${ }^{37}$ The children also had their own special vegetable garden, from which all profits from the sale of vegetables was donated to the Red Cross to help pay for food parcels for Australian soldiers who had been taken as prisoners-of-war by Germany. Similarly, the women at the Station, under the auspices of the Aborigines' Ladies Guild, continued to raise funds through selling handicrafts, vegetables and second-hand clothes. In 1944 they were also reported as being regular donors to the Red Cross in support of its acquisition and distribution of food parcels to Australian POWs. ${ }^{38}$

While the stated objective of the Aborigines' Ladies Guild was to support Australia's war work, it is apparent that another broader social objective also underpinned its founding. In its report on the Cabbage Tree Island Aboriginal Station for 1940, Lismore's Northern Star newspaper observed how 'the past year ... has been one of considerable progress' ${ }^{39}$ The types of events that the Guild members helped organise, characterised as they were by strong Western cultural and religious elements, provided strong evidence of what was taken, at the time, as evidence of advancement towards civilisation and integration. When read alongside accounts of local Aboriginal men signing up to serve Australia during the Second World War, the assimilationist undertones were even stronger. The way in which the Guild's formation and subsequent activities was lauded as a sign of Aboriginal progression towards eventual assimilation into wider Australian society was consistent with one of the five stated aims of the Aborigines Welfare Board (which in 1940 had replaced the Aborigines Protection Board), an organisation that Heather Goodall has described as trying

\footnotetext{
36 Northern Star, 6 January 1941; Aborigines Welfare Board Report for the Year Ended 30th June 1940, Parliament of New South Wales (Second Session), 1941.

37 Northern Star, 20 August 1942.

38 Muswellbrook Chronicle, 27 June 1944.

39 Northern Star, 6 January 1941.
} 
'to continue its predecessor's concentration policy'.$^{40}$ The Board's fifth stated aim delineated the pursuit of 'a policy which would result in the gradual assimilation of aborigines into the general and social life of the general community, special attention being given to each individual aboriginal family and their suitability for assimilation by virtue of education, training and personal qualities'. ${ }^{41}$ Such training was later elaborated as including 'handicraft classes on the stations', with the aim of such training ultimately being the assimilation of 'the aborigines, particularly those with lighter caste, into the general community' ${ }^{42}$ A further assimilatory impetus can be seen in the way in which Aboriginal people were engaged in cultivating vegetables. This was consistent with the Aborigines Welfare Board's aim to provide station residents with 'garden space around their homes, with the object of encouraging them to form and cultivate vegetable and flower gardens'. The objectives behind encouraging gardening were to provide a ready supply of fresh vegetables and to beautify the homes on the stations. This would benefit the Board in terms of reduced costs and potentially benefit the residents in terms of improved health if they were to consume the fresh produce through providing a more 'balanced ration'. Gardens would also further encourage practices that saw Aboriginal people comply with white expectations in regard to the cultivation of land and exhibiting pride in the presentation of one's home. ${ }^{43}$

The official policies of the Aborigines Welfare Board did not necessarily reflect the views of all of those living locally along the north coast of New South Wales. As John Maynard has noted in relation to Aboriginal activism in the early decades of the twentieth century, 'the response to the AAPA's [Australian Aborigines Progressive Association's] activities was strongest in areas where widespread loss of land and children was being most savagely experienced', which was certainly the case in this region. Interestingly, such hardships contributed not only to a large turnout of Aboriginal participants at the AAPA's second annual conference held in Kempsey in 1925, but also to support from 'high profile local dignitaries' and associations. ${ }^{44}$ The comforts fund activities organised in this region therefore need to be read against this backdrop of what was a complicated history, just as each other region has its own particularities.

\footnotetext{
40 Goodall 1996: 264.

41 Aborigines Welfare Board Report for the Year Ended 30th June 1940, Parliament of New South Wales (Second Session), 1941.

42 Aborigines Welfare Board Report for the Year Ended 30th June 1941, Parliament of New South Wales.

43 Aborigines Welfare Board Report for the Year Ended 30th June 1940, Parliament of New South Wales (Second Session), 1941; Aborigines Welfare Board Report for the Year Ended 30th June 1941, Parliament of New South Wales.

44 Maynard 2007: 71-73.
} 


\section{Cummeragunja Aboriginal Station}

Cummeragunja Aboriginal Station, which became a reserve post-Second World War, was a government-run facility located in country New South Wales adjacent to the Murray River and about 30 kilometres north-east of Echuca in Victoria. In 1939, it became the site of a major Aboriginal walk off as the residents protested the conditions under which they were being forced to live. The tensions evident at this site at the time beg the question as to why Aboriginal women and children contributed to the war effort through producing comforts for soldiers, an activity that was viewed by the Aborigines Protection Board as evidence of their patriotism and which it utilised as propaganda in support of assimilation. While there is limited scope within the parameters of this article to explore this topic in depth, engaging with some of the key factors that converged to facilitate the production of comforts at Cummeragunja are a useful reminder of Aboriginal agency, the long histories of such sites, and the importance of appreciating local specificity within a relevant national and international framework.

The site at which Cummeragunja stood was, in the mid-nineteenth century, known as Maloga mission. As Christina Twomey and Andrew May have demonstrated, there was a long history in the contact period of Aboriginal people at this site providing assistance to those considered even less fortunate than themselves. Twomey and May highlighted, for example, how Maloga Aboriginal School students contributed to the Victorian Famine Relief Fund established in the late 1870s to address the plight of Indian people suffering the impacts of the 1876-1878 Indian famine. At the time, their involvement in this charitable work was read as evidence of Aboriginal people having a greater depth of feeling than that for which they were usually given credit. ${ }^{45}$

In 1881, many of the Aboriginal people who resided at the Maloga mission moved a short distance away to the then newly opened Cummeragunja Aboriginal Station. As the nineteenth century gave way to the twentieth, conditions for Aboriginal people living on Cummeragunja deteriorated in tandem with greater control being exerted over their lives by the Aborigines Protection Board. During the inter-war years, as was the case across many Aboriginal stations and missions at the time, Cummeragunja residents were concerned about a broad range of issues. High unemployment had seen more demand on station housing, increased pressure on rations, and a marked deterioration in people's health through living in close proximity in crowded and unsanitary conditions. The station's water pump had stopped working, and increasing numbers of residents were suffering from the eye disease trachoma. While the station was 
on a sizeable parcel of land, 2,000 acres had been leased to a neighbouring white farmer with only 14 acres being reserved for the Aboriginal residents' use. In a pattern of conflict only too familiar to Australians, the white farmer stood accused by the station residents of siphoning off most of their water supply, leaving the Cummeragunja cattle in poor condition. To make matters worse, in November 1937 the Aborigines Protection Board had transferred a new manager, Arthur McQuiggin, onto the station. McQuiggin had formerly been in charge of the Kinchela Boys' Home. He and his wife, who functioned as the station's matron, became sufficiently unpopular for former Cummeragunja resident and secretary of the Aborigines Advancement League, William Cooper, to petition the Aborigines Protection Board for their removal. ${ }^{46}$

The 1930s was characterised by a rise in Aboriginal activism built on the groundwork laid by leading twentieth-century Aboriginal activists such as Fred Maynard in the preceding decade. ${ }^{47}$ This saw the conditions under which Aboriginal people were being forced to live as well as their own aspirations for their futures being articulated collectively through spokespeople such as Cooper, and Aborigines Progressive Association President Jack Patten. Patten was disturbed by the relatively high death toll at Cummeragunja, and publicised the matter in the media. On 2 February 1939, he visited Cummeragunja and addressed the station's residents. The following day, around 100 Aboriginal people walked off the station, with many families staying away over the months that followed. While the walk off initially garnered local media interest, the news story was ultimately subsumed by the outbreak of the Second World War in September of the same year. ${ }^{48}$

Pressure from Aboriginal activists and their white supporters such as Burdeu led to inquiries, such as the New South Wales Parliamentary Select Committee convened in 1937 to 'inquire into the administration' of the Aborigines Protection Board. While the Select Committee failed to furnish a report, the Public Services Board ultimately recommended that the Protection Board be replaced. Accordingly, the Aborigines Welfare Board was appointed under the provisions of the Aborigines Protection (Amendment) Act 1940 (NSW). ${ }^{49}$

Despite the increasingly difficult conditions under which Aboriginal people lived at Cummeragunja, the women and children acquired skills that were highly relevant to the provision of comforts during the Second World War. Just a couple of years prior to the outbreak of the Second World War, in March 1937, the co-director of the Aborigines Inland Mission of Australia, Retta Long, visited

\footnotetext{
46 Davis 2014: 122-123.

47 See, in particular, Maynard 2007.

48 Davis 2014: 117-126.

49 Aborigines Welfare Board Report for the Year Ended 30th June 1940, Parliament of New South Wales (Second Session), 1941.
} 
Cummeragunja, where she was impressed by the sewing skills exhibited by the women. As Fiona Davis has explained, the women were 'already experienced in making their own frocks, [and] were working on garments to send to Aboriginal people at Tennant Creek'. The missionary, according to Davis, 'saw a sign of successful civilisation', and was gratified to see the Aboriginal women at the reserve working to help those at Tennant Creek whom Long saw as being worse off than the reserve residents. ${ }^{50}$ The long tradition of Cummeragunja residents helping others viewed as less fortunate continued.

As well as having developed skills in sewing, the women at Cummeragunja knew how to knit. They were instructed in this by Beatrice Austin, their teacher's wife, a woman later described by one of Davis' Aboriginal informants, Lorna Walker, as having been 'a small woman with dark brown hair'.$^{51}$ Walker recalled how, in addition to teaching her and other girls how to knit, Austin had also taught them needlework. Another of Davis' informants, Melva Johnson, also remembered being taught to knit by Austin, as well as how to weave baskets and to clean. 'Those are the things they learnt us', she told Davis, 'the skills that we sort of carried with us. Cause not many of us went on to anything else but being domestics'. ${ }^{52}$ As well as preparing Aboriginal girls for roles as domestic servants, which were seen at the time as fitting both in terms of providing white employers with inexpensive assistance and equipping young Aboriginal women with the knowledge and experience eventually to run their own homes as assimilated Australians, the acquisition of sewing and knitting skills meant the women were well-suited to assist with the war effort through the provision of comforts.

Although they resided in New South Wales, the women at Cummeragunja created comforts under the auspices of the Victorian-based Echuca Group RSL War Service Fund which, by November 1940, had been amalgamated with the Australian Comforts Fund. In its report on the number of articles forwarded from Echuca to Melbourne during the month of October 1940, the Riverine Herald reported that ' 19 scarves, 9 pairs of socks, 15 pairs of mittens, 2 helmets, [a] pair of spiral socks, [and a] pair of gloves' had been received from the women at Cummeragunja. ${ }^{53}$ At the time, 207 Aboriginal people were reported as living on the station, although no further information is available to indicate how many of that number were adults, nor how many were female. ${ }^{54}$ The articles knitted at Cummeragunja covered almost the entire range of the 2,851 articles which

\footnotetext{
50 Davis 2014: 2-3, 58.

51 Davis 2014: 98.

52 Davis 2010: 169.

53 Riverine Herald, 14 November 1940.

54 Aborigines Welfare Board Report for the Year Ended 30th June 1940, Parliament of New South Wales (Second Session), 1941.
} 
by that date had been forwarded from Echuca to Melbourne, and represented around 10 per cent of the monthly total from Echuca. The work of the local comforts committee was said to be 'functioning exceedingly smoothly, owing to the well organised efforts of the ladies' committee in conjunction with the willing band of helpers and knitters', with the Cummeragunja women's efforts receiving a special mention. ${ }^{55}$

It was against the backdrop of Aboriginal unrest at Cummeragunja that the Aborigines Welfare Board utilised a series of photographs of Aboriginal women and girls from the station in the widely read Pix magazine in November 1941 to cast its work in a positive light. At least one of these photographs, now held in the collection of the Australian War Memorial, was taken by Beatrice Austin, the teacher's wife who taught the women to knit. It depicts 24 women and girls of varying ages, all dressed neatly in typical Australian female attire of the period, arranged in two rows, one seated with another standing behind them. Each of the females is shown holding her knitting in progress, with a number of completed socks, balaclavas, and jumpers produced by the women for Australian soldiers serving abroad being foregrounded in the staged photograph. As Jane Lydon has pointed out, drawing on Edward Said's work, 'apparently neutral ... representations of Aboriginal people can be shown to serve a functional purpose for white society' ${ }^{56}$ On the surface, this photograph paid tribute to the Cummeragunja women's contribution of comforts to assist the war effort, and, more obliquely, to the numbers of men from the station who had voluntarily joined the armed forces. Yet its overriding message was one in which the Board congratulated itself on its visually apparent progress towards preparing the station residents for assimilation into the wider Australian community.

55 Riverine Herald, 14 November 1940.

56 Lydon 2004: 60. 


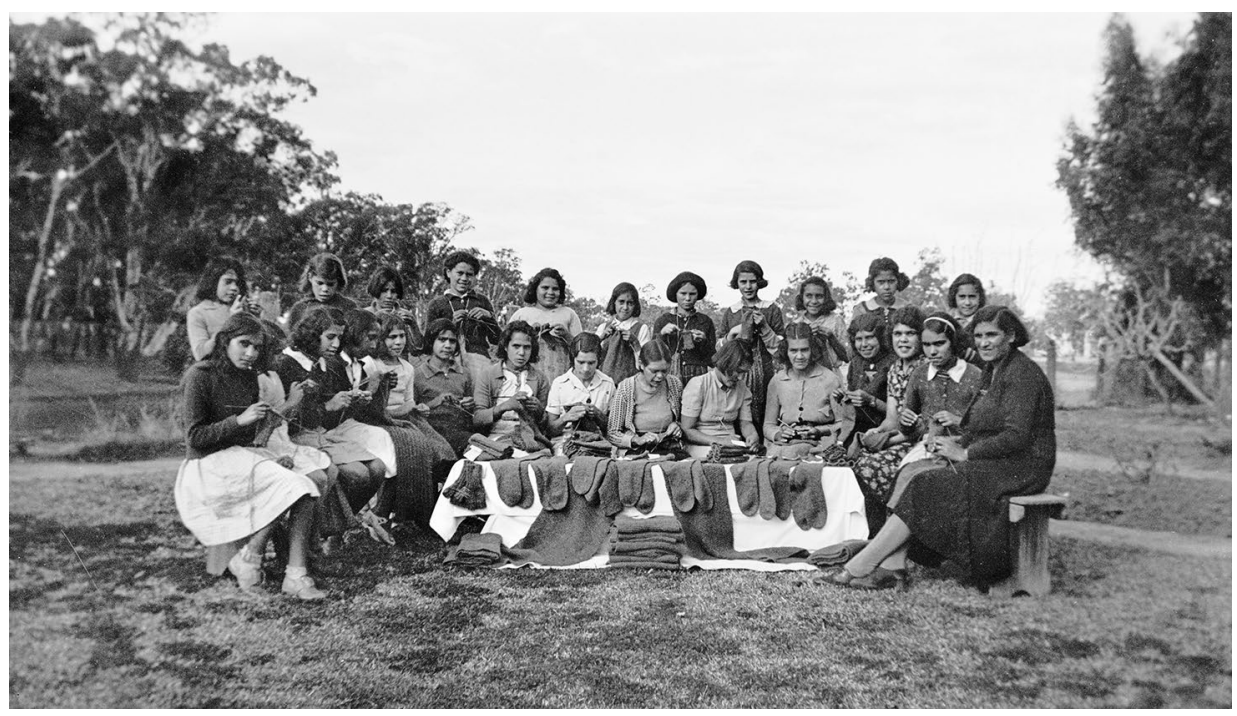

Figure 1: Group portrait of Aboriginal women and girls knitting socks, jumpers and balaclavas for the war effort at Cumeroogunga Government Mission, New South Wales (opposite Barmah, Victoria) on the Murray River.

Identified, left to right, back row: Merle Morgan, June Morgan, Weeny Charles, Amy Briggs, Valda McGee, Edna Walker, Sheila Charles, Joan Charles, Elsie Cooper, Midge Walsh, Florry Walker. Front row: Joyce Atkinson, Clare Charles, Alma Charles, Ada Cooper, Nelly Davis?, Elizabeth Morgan, Lauraine Charles, Greta Cooper, Violet Charles, Wynnie Walker, Hilda Walker, Georgina Atkinson, Lydia Morgan, Reta Cooper, Maggie Weston. Photographer: Beatrice Austin, 1941.

Source: Courtesy Australian War Memorial: P01562.001.

Such overt usage of Aboriginal photographs to promote progress towards assimilation had also been evident in relation to Cummeragunja in January 1938, when a polio outbreak at the station had given media outlets cause to trumpet the 'good work settler society was doing for its Aboriginal population'. As Davis has pointed out, the Argus, for example, speciously utilised the occasion to promote the idea that the Aboriginal people at Cummeragunja lived contentedly in their own homes, enjoying similar facilities as the residents of most country towns. This was far from being the lived experience of those at the station. ${ }^{57}$

\section{Conclusion}

While a paucity of surviving evidence has rendered it nigh on impossible to quantify the reach and impact of the Aborigines Uplift Society's national comfort auxiliary, qualitative evidence has suggested that the majority of

57 Davis 2014: 111-116. 
its volunteers came from the white middle classes. Some white middle-class volunteers were surprised to find their Aboriginal correspondents literate, unsettling their notions of what it might have meant to be an Aboriginal person in mid-twentieth-century Australia. Nevertheless, surviving evidence has also indicated that affective relationships formed between some of these Aboriginal soldiers and their white correspondents, at least across the temporal and spatial divides rendered by war.

The comfort auxiliary was founded on the basis that Aboriginal women were too impoverished to send comfort parcels to their men serving abroad, yet it is evident that at least some community members, albeit often living under the constraints of mission, station or reserve life, were able to do so. In some instances, such as at Stradbroke Island, the production of comforts was seen as breaking down the colour bar between local Aboriginal and white women.

Most Aboriginal contributions were channelled through mainstream patriotic funds, such as the Red Cross and the Australian Comforts Fund, and were demonstrably appreciated at a very practical and emotional level by the recipients. This can be seen, for example, following the repatriation of Private Clarrie Combo (the soldier who had corresponded with Mrs Brown from Loxton, and whose family lived at Cabbage Tree Island) and two companions in August 1942. At one of several 'welcome home' events, Combo's companions, Privates Dan Buckley and Cedric Lofts, informed the gathering at the hall in Tregeagle how grateful they had been for the parcels of comforts that had been sent to them by the Tregeagle Soldiers' Welfare Association. ${ }^{58}$

Aboriginal people at stations such as Cummeragunja, where there was a long history of providing for those elsewhere who were considered even worse off than the Aboriginal station inhabitants, may have genuinely enjoyed knitting comforts for soldiers serving abroad, and Aboriginal soldiers appreciated receiving comfort parcels. State authorities such as the New South Wales Aborigines Welfare Board capitalised on Aboriginal involvement in the global theatre of war to promote positive visual images of itself and its assimilatory agenda. Regardless of such visions of equality, however, Aboriginal men, women and children did not find themselves on an equal footing with other Australians at the conclusion of the Second World War. 


\section{References}

\section{Primary sources}

\section{National Library of Australia}

Uplift: The Official Organ of the Aborigines Uplift Society

\section{Parliament of New South Wales}

Aborigines Welfare Board Report for the Year Ended 30th June 1940

Aborigines Welfare Board Report for the Year Ended 30th June 1941

Aborigines Welfare Board Report for the Year Ended 30th June 1945

\section{State Library of Victoria}

BARIO1976, 'Leaguery' [4], Primary Records of the Aborigines Uplift Societies, Series 28: Aboriginal Rights Movement in Australia - Educational and Promotional Material, Diane Barwick Papers

\section{Newspapers and periodicals}

The Advertiser (Adelaide)

Camperdown Chronicle

The Courier Mail

The Examiner

The Murray Pioneer and Australian River Record

The Muswellbrook Chronicle

The Northern Star

The Queensland Times (Ipswich)

The Richmond River Herald and Northern Districts Advertiser

The Riverine Herald

The West Australian 


\section{Secondary sources}

Attwood, Bain and Andrew Markus 2004, Thinking Black: William Cooper and the Australian Aborigines' League, Aboriginal Studies Press, Canberra.

Beaumont, Joan 2014, Broken Nation: Australians in the Great War, Allen \& Unwin, Crows Nest, NSW.

Davis, Fiona 2010, 'Colouring within the lines: settler colonialism and the Cummeragunja Aboriginal Station, 1888-1960s', PhD thesis, School of Historical Studies, University of Melbourne.

2014, Australian Settler Colonialism and the Cummeragunja Aboriginal Station, Sussex Academic Press, Brighton.

Goodall, Heather 1996, Invasion to Embassy: Land in Aboriginal Politics in New South Wales, 1770-1972, Allen \& Unwin, St Leonards.

Hall, Robert 1995, Fighters from the Fringe: Aborigines and Torres Strait Islanders Recall the Second World War, Aboriginal Studies Press, Canberra.

-1997, The Black Diggers: Aborigines and Torres Strait Islanders in the Second World War, Aboriginal Studies Press, Canberra.

Harman, Kristyn 2013, 'Protecting Tasmanian Aborigines: American and Queensland influences on the Cape Barren Island Reserve Act, 1912', Journal of Imperial and Commonwealth History 41(5): 744-764.

-2015, “Doing a grand job": Tasmanian Girl Guides and their service across two world wars', Tasmanian Historical Studies (in press).

Huggonson, David 1994, 'World War: The start of political battle for Indigenous Australians', ATSIC News, 10-11.

Lydon, Jane 2004, “This civilising experiment": Photography at Coranderrk Aboriginal Station during the 1860s', in After Captain Cook: The Archaeology of the Recent Indigenous Past in Australia, Indigenous Archaeologies Series, Rodney Harrison and Christine Williamson (eds), AltaMira Press, Maryland: 59-74.

Maynard, John 2007, Fight for Liberty and Freedom: The Origins of Australian Aboriginal Activism, Aboriginal Studies Press, Canberra.

McKernan, Michael 2014, Australians at Home: World War II, Five Mile Press, Scoresby, Vic. 
O'Brien, Anne 2015, Philanthropy and Settler Colonialism, Palgrave Macmillan, New York.

Oppenheimer, Melanie 2004, 'Controlling civilian volunteering: Canada and Australia during the Second World War', War and Society 22(2): 27-50.

Paisley, Fiona 2000, Loving Protection? Australian Feminism and Aboriginal Women's Rights, 1919-1939, Melbourne University Press, Melbourne.

Ramsland, John and Christopher Gerald Mooney 2006, Remembering Aboriginal Heroes, Brolga Publishing, Melbourne.

Riseman, Noah 2014, 'Aboriginal military service and assimilation', Aboriginal History 38: 155-178.

-2015, 'Escaping assimilation's grasp: Aboriginal women in the Australian Women's Military Services', Women's History Review: 24(5): 757-775.

Saunders, Kay 1995, 'Inequalities of sacrifice: Aboriginal and Torres Strait Islander labour in northern Australia during the Second World War', Labour History 69: 131-148.

Scates, Bruce 2001, 'The unknown sock knitter: Voluntary work, emotional labour, bereavement, and the Great War', Labour History 81: 29-49.

Thomson, Donald 2005, Thomson in Arnhem Land, Miegunyah Press, Carlton.

Twomey, Christina and Andrew J May 2012, 'Australian responses to the Indian famine, 1876-78: Sympathy, photography and the British Empire', Australian Historical Studies 43(2): 233-252. 
This text is taken from Aboriginal History, Volume 39, 2015, edited by Liz Conor, published 2015 by ANU Press,

The Australian National University, Canberra, Australia. 